\title{
NOTE
}

\section{How deep can baleen whales dive?}

\author{
Simone Panigada*, Margherita Zanardelli, Simonepietro Canese, Maddalena Jahoda \\ Tethys Research Institute, Acquario Civico, Viale G.B. Gadio 2, 20121 Milan, Italy
}

\begin{abstract}
This paper presents evidence of deep diving performances by fin whales Balaenoptera physalus in the Mediterranean Sea, never directly recorded for any other species of baleen whales. By means of velocity-time-depthrecorders applied to the whales with suction cups, depths of at least $470 \mathrm{~m}$ were registered twice, over 7 dives below $150 \mathrm{~m}$ recorded during a total of $12 \mathrm{~h} 38 \mathrm{~min}$ of remote tracking. The deep bouts occurred in late afternoon, in coincidence with the diel vertical upward migration of krill Meganyctiphanes norvegica, the principal prey species for Mediterranean fin whales. The data presented indicate that fin whale diving capabilities are opportunistically adapted to deep prey availability in the area.
\end{abstract}

KEY WORDS: Deep diving - Fin whale - Mediterranean Sea Feeding ecology $\cdot$ Telemetry $\cdot$ Krill migration

Since the early 1900 s baleen whales have been described as shallow divers, with dives seldom deeper than 100 to $150 \mathrm{~m}$, because the krill on which they prey was thought to be rarely abundant at greater depths (Laurie 1933). At present, krill is known to occur at depths greater than $1000 \mathrm{~m}$ in some areas, but there is still poor knowledge regarding the diving capabilities of many cetacean species, particularly mysticetes.

In this paper we report the first successful tagging of fin whales Balaenoptera physalus from the Mediterranean Sea with velocity-time-depth-recorder (VTDR). Seven dives below $150 \mathrm{~m}$ were recorded, 2 of which reaching a depth of at least $470 \mathrm{~m}$.

Unlike some teutophagous odontocetes, such as the sperm whale Physeter macrocephalus which is known to reach depths of $3000 \mathrm{~m}$ (Schreer \& Kovacs 1997), baleen whales are generally considered to be shallow divers, even if they are capable of deeper dives (Ommanney 1932, Gaskin 1982, Leatherwood et al.

•E-mail: panigada@tin.it
1982, Hamilton et al. 1997). In the past, most divingdepth data were inferred from whales that were harpooned, echosounder data, and assumptions based on depth distributions of their typical prey species (Scholander 1940, Hamilton et al. 1997).

The fin whale is the only mysticete regularly occurring in the Mediterranean Sea and is rather abundant in the northwestern part of the basin during summer (Duguy 1990). Genetic analyses, performed on fin whale biopsy samples collected in North Atlantic and Mediterranean Sea summer feeding grounds, suggested that Mediterranean whales constitute a separate population, with limited gene flow between them and North Atlantic conspecifics (Bérubé et al. 1998). The fin whale population in the western Mediterranean Sea has been estimated at 3500 individuals during the summer, based on line transect sampling methods (Forcada et al. 1996). Approximately 900 of these whales concentrate in the Corso-Ligurian Basin (Forcada et al. 1995), which is believed to represent their primary feeding area (Zanardelli et al. 1998). The basin is characterized by high productivity and supports a large biomass of euphausiids dominated by Meganyctiphanes norvegica (Casanova 1970), one of the principal prey species of fin whales (Jonsgard 1966).

Materials and methods. Between 19 June and 24 September 1998, research cruises were conducted aboard a $19.8 \mathrm{~m}$ long auxiliary sailing vessel, equipped with a fiberglass-keel inflatable craft powered by a $25 \mathrm{Hp}$ outboard engine. The study area (Fig. 1) included the offshore waters of the western Ligurian Sea between San Remo (Italy), the French Riviera, and the Island of Corsica. During the study period 6 fin whales were tagged with Mk6 model (Wildlife Computers, Redmond, WA) V-TDRs that were remotely attached by means of a suction cup. The V-TDR used had a depth range of 0 to $500 \mathrm{~m}$ and a depth sensor accuracy of $1 \%$ of the reading $\pm 2 \mathrm{~m}$. Water temperature, speed 


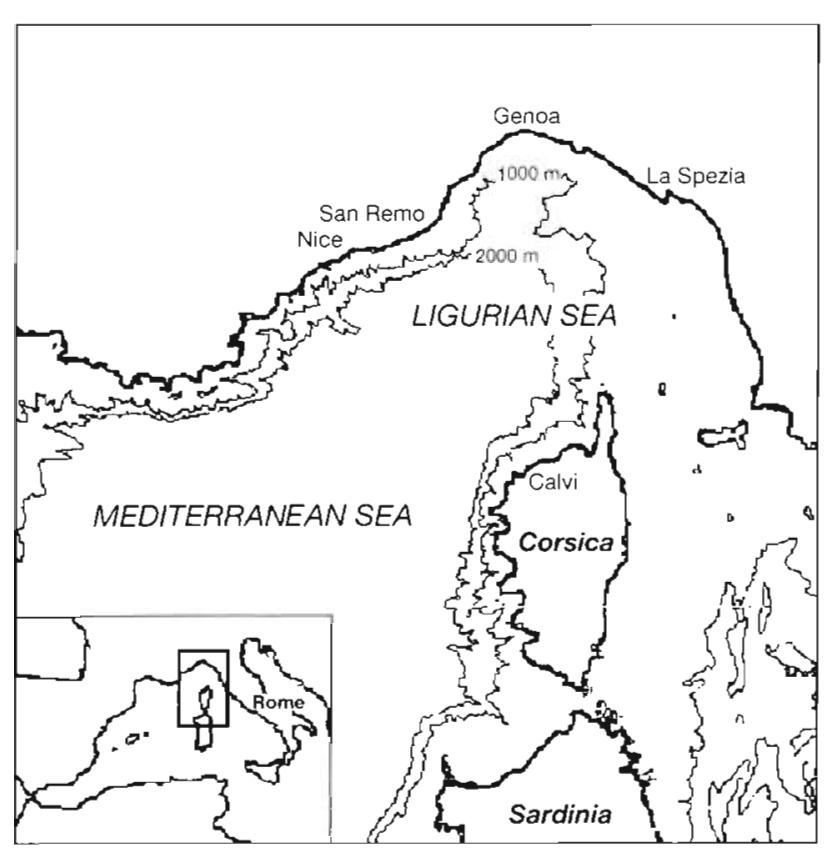

Fig. 1. The study area

of the whale, and depth of dives were sampled at $2 \mathrm{~s}$ intervals. Each tag was equipped with a VHF radio (Advanced Telemetry Systems, Isanti, MN). This allowed us to follow the whale while at the surface and to facilitate tag recovery after spontaneous detachment from the whale, by means of a VHF receiver and a directional antenna on board the research vessel.

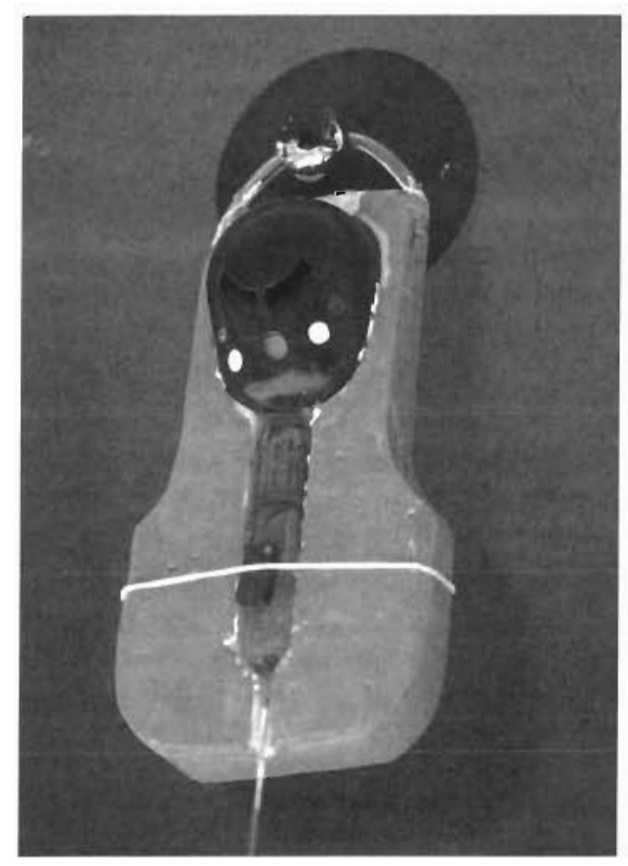

Fig. 2. The epoxy resin tag
The tag on which the instruments were encased was built in epoxy resin with glass micro-bubbles to provide buoyancy; it weighed $375 \mathrm{~g}$ and measured $20 \mathrm{~cm}$ in length (Fig. 2).

The whales were approached with the inflatable craft and tags were deployed using a $6 \mathrm{~m}$ long aluminum pole. In order to increase the time of permanence on the whale and collect sloughed skin for genetic analyses, the interior of the suction cup was covered with a thin layer of silicon grease.

Results and discussion. The tags remained on the whales (Fig. 3) for periods ranging from $10 \mathrm{~min}$ to $8 \mathrm{~h}$ $23 \mathrm{~min}$. This allowed us to collect $12 \mathrm{~h} 38 \mathrm{~min}$ of dive data for fin whales coincident with their presumed foraging activity. Two whales performed deep dives: one dove up to $194 \mathrm{~m}$, and another reached on 2 occasions depths of at least $470 \mathrm{~m}$ - which represents the instrumental limit-and once the depth of $420 \mathrm{~m}$. The latter whale was tagged on 19 July at 09:45 h and followed until 18:08 $\mathrm{h}$, when the detached tag was recovered. The data collected indicated that until 17:00 h the whale remained close to the surface performing 39 shallow dives of less than $100 \mathrm{~m}$ (mean depth $=24.5 \mathrm{~m}, \mathrm{SD}=15.6)$ with a mean duration of $7.1 \mathrm{~min}(\mathrm{SD}=2.5)$. Deeper and longer dives began after the shallow diving bouts (Fig. 4). On 2 consecutive bouts, the whale dove up to a depth of at least $470 \mathrm{~m}$, with apneas lasting 11.7 and $12.6 \mathrm{~min}$. The whale remained in proximity of this depth for 4.6 and $6.1 \mathrm{~min}$, respectively. During deep dives the depth sensor stopped recording data at $470 \mathrm{~m}$ for a maximum period of $82 \mathrm{~s}$; therefore, given a mean speed of $1.7 \mathrm{~m} \mathrm{~s}^{-1}$ for this $82 \mathrm{~s}$ period, we suggest that the maximum depth reached by the tagged whale may be estimated at $542 \mathrm{~m}$ (if the whale had gone straight down and up). Mean descent and ascent swimming speeds for these dives were $3.2(\mathrm{SD}=1.82)$ and $2.1 \mathrm{~m} \mathrm{~s}^{-1}(\mathrm{SD}=0.82)$, respectively. While performing a third dive, the tag detached at $420 \mathrm{~m}$ and was recovered at the surface.

The depth distribution of prey for fin whales in the Mediterranean Basin is atypical compared to other areas, because Meganyctiphanes norvegica remains at depths exceeding 500 and even $1000 \mathrm{~m}$ for most of the day and migrates, with amplitudes up to $600 \mathrm{~m}$, towards shallower depths in the late afternoon (Casanova 1970, Sardou et al. 1996). Our data indicated that fin whales in this region exhibited 2 distinct diving patterns, with shallow and deep dives performed at different times of the day, in relation to diel vertical migrations of the krill. These data indicate that fin whales may forage opportunistically at deep depths in order to exploit deep prey resources. Mediterranean fin whales, in particular, may have adapted to vertical prey distribution by developing deep-diving capabilities and opportunistic behavioral patterns suited to match diel vertical migrations of their prey. 
Fig. 3. The tag attached to the whale

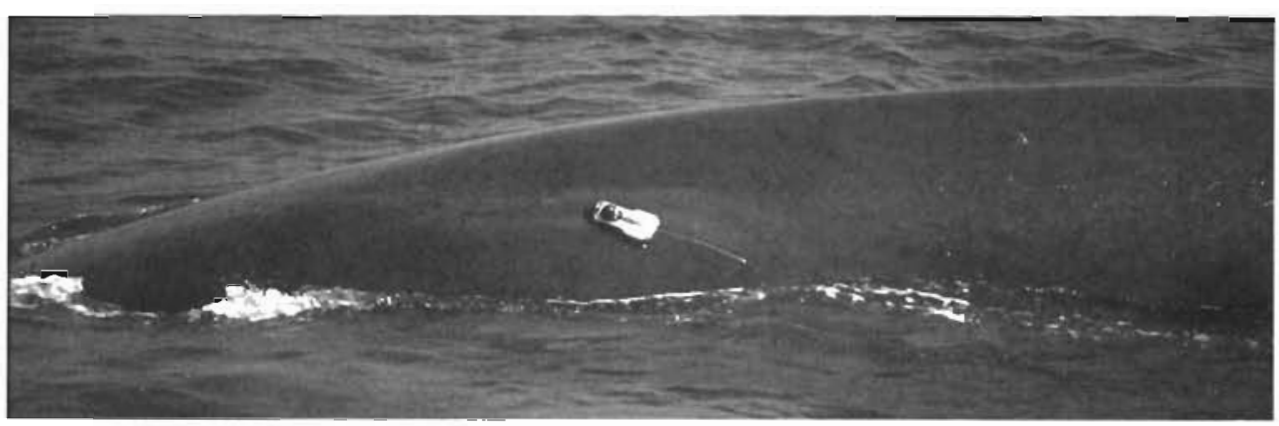

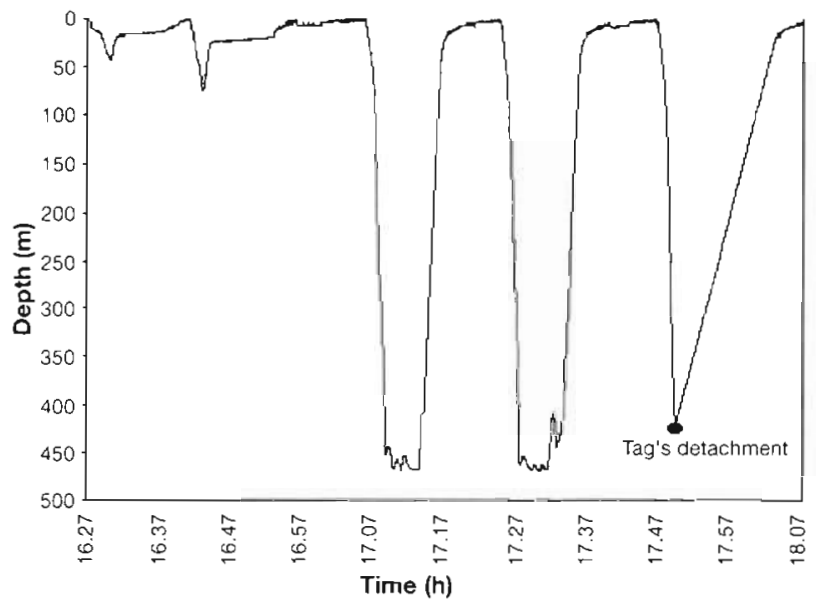

Fig. 4. Balaenoptera physalus. A fin whale's deep diving profile

These results represent the maximum depths ever directly registered for any mysticete species. Evidence of deep diving by fin whales substantially challenges our current understanding of the species' diving capabilities. In light of the maximum depths of dives recorded here, revision is required regarding current assumptions on the feeding ecology and energetics of this and other mysticete species.

Acknowledgements. We wish to thank Robin Baird for precious advice and support. Special thanks go to Mr Gianni Cozzi and Mr Pierfranco Gavagnin, Portosole Sanremo, Italy, for their support and hospitality. Thanks to J. Fabrizio Borsani for providing the recipe for the epoxy resin. Many thanks to Mark Benfield, Giuseppe Notarbartolo di Sciara, Phil Clapham, and Peter Wiebe for helpful comments on an earlier draft of the manuscript and to the anonymous reviewers, who improved the final version. George $M$. Paximadis shared the exciting moments of the first tagging. Last but not least, we would like to thank Giovanni Bearzi for valuable comments and editorial criticism on the manuscript. The research cruises of our vessel 'Gemini Lab' were supported in part by funds collected through eco-volunteer programs.

\section{LITERATURE CITED}

Bérubé $M$, Aguilar A, Dendanto D, Larsen F, Notarbartolo di Sciara G, Sears R, Sigurjonsson J, Urban-R J, Palsboll P (1998) Population genetic structure of North Atlantic, Mediterranean Sea and Sea of Cortez fin whales, Balaenoptera physalus (Linnaeus 1758): analysis of mitochondrial and nuclear loci. Mol Ecol 7:585-599

Casanova B (1970) Répartition bathymétrique des euphausiacés dans le bassin occidental de la Méditerrané. Rev Trav Inst Pêches Marit 34(2):205-219

Duguy R (1990) Les mammifères marins de la Méditerranée occidentale. Bull Soc Zool Fr 114:89-96

Forcada J, Notarbartolo di Sciara G, Fabbri F (1995) Abundance of fin whales and striped dolphins summering in the Corso-Ligurian Basin. Mammalia 59(1):127-140

Forcada J, Aguilar A, Hammond P, Pastor X, Aguilar R (1996) Distribution and abundance of fin whales (Balaenoptera physalus) in the western Mediterranean sea during the summer. J Zool Lond 238:23-34

Gaskin DE (1982) The ecology of whales and dolphins. Heineman Press, London

Hamilton PK, Stone GS, Martin SM (1997) Note on a deep humpback whale Megaptera novaeangliae dive near Bermuda. Bull Mar Sci 61(2):491-494

Jonsgard A (1966) Biology of the North Atlantic fin whale Balaenoptera physalus (L). Hvalradets Skr 49:1-62

Laurie AH (1933) Some aspects of respiration in blue and fin whales. Discovery Rep 7:363-406

Leatherwood S, Reeves RR, Perrin WF, Evans WE (1982) Whales, dolphins, and porpoises of the eastern North Pacific and adjacent arctic waters. NOAA Tech Rep NMFS Circ No. 444, US Department of Commerce, Seattle, WA

Ommanney FD (1932) The vascular networks (retia mirabilia) of the fin whale (Balaenoptera physalus). Discovery Rep 5: $327-465$

Sardou J, Etienne M, Andersen V (1996) Seasonal abundance and vertical distributions of macroplankton and micronekton in the Northwestern Mediterranean Sea. Oceanol Acta 19(6):645-656

Scholander PF (1940) Experimental investigations on the respiratory function in diving mammals and birds. Hvalradets Skr 22:1-131

Schreer JF, Kovacs KM (1997) Allometry of diving capacity in air-breathing vertebrates. Can J Zool 75:339-358

Zanardelli M, Panigada S, Airoldi S, Borsani JF, Jahoda M, Notarbartolo di Sciara G (1998) Site fidelity, seasonal residence and sex ratio of fin whales (Balaenoptera physalus) in the Ligurian Sea feeding grounds. In: Abstracts of the World Marine Mammal Science Conference, Monaco, 20 to 24 January 1998. Centre de Recherche sur les Mammifères Marins, La Rochelle, p 154 